\title{
Marine mammals observations in the Gulf of Guayaquil on the south coast of Ecuador in May-June 2013
}

\author{
Andrew G. Bublichenko
}

\begin{abstract}
Marine mammal (MM) observations were carried out during seismic survey of a $37 \mathrm{~km}^{2}$ area in water depths ranging from 37-58 $\mathrm{m}$ in the Gulf of Guayaquil in May- June 2013. Twenty-one encounters with individual MMs or groups of MMs were recorded during 216 hours of observer effort. Bottlenose dolphins were most frequently seen, but observers also recorded the presence of striped dolphins and of humpback and killer whales and of sea lions. This short paper presents companion meteorological observations and considers the influence of weather and other environmental conditions on the frequency of the MM encounters.
\end{abstract}

KEY WORDS: Ecuador, the Gulf of Guayaquil, Santa Clara Island, marine mammals.

Andrew G. Bublichenko [abublichenko@mail.ru], Zoological Institute, Russian Academy of Science, Universitetskaya nab. 1, Saint Petersburg, 199034, Russia.

\section{Наблюдения за морскими млекопитающими в заливе Гуаякиль на южном побережье Эквадора в мае-июне 2013 г.}

\section{А.Г. Бубличенко}

\begin{abstract}
РЕЗЮМЕ. Наблюдения за морскими млекопитающими (ММ) выполнялись в рамках сейсморазве-

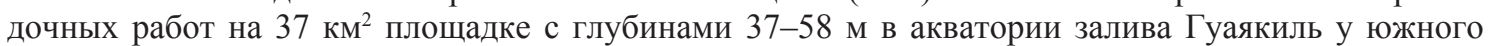
побережья Эквадора в мае-июне 2013 г. Всего за 216 часов наблюдений зарегистрирована 21 встреча ММ 5 видов. В работе представлены данные по объему метеорологических наблюдений, рассмотрено влияние внешних условий на частоту встреч ММ, приведен краткий обзор данных учетов по каждому виду.
\end{abstract}

КЛЮЧЕВЫЕ СЛОВА: Эквадор, залив Гуаякиль, о-в Санта-Клара, морские млекопитающие.

\section{Introduction}

The interest for the environmental systems of the Gulf of Guayaquil caused by activities in geological prospecting and, inter alia, seismic survey operations create a noticeable disturbance factor for marine mammals and seabirds, irrespectively of their permanent residence in this area or occurrence here during migration periods.

The surface area of the Gulf of Guayaquil is more than $12000 \mathrm{~km}^{2}$, this is the most extensive estuary of the Pacific shore of the South America. In the north, Guayas River discharges into the gulf. The largest of the gulf islands, Puna Island is situated in its mouth. Santa Clara Island, a small rocky island with unique seabird colonies is situated in the central part of the gulf, $30 \mathrm{~km}$ off shore. Back in 1999, Santa Clara Island was declared a national wildlife reserve. Since 2002, it is a part of the Ramsar Convention of wetland sites.

Humpback whales migration routes pass through the Gulf of Guayaquil. The main area of the MM synoecium is the northern part of the gulf (Santa Elena Peninsula) and the coastal area of the Puna Island; the factors determining this are the shoreline configuration, water depth and bottom topography.
To understand the distribution and abundance of the five species of MMs seen in the area of our survey, it is important to describe the overall marine ecosystem in the coast water of Ecuador. Therefore, brief mention will be made of the available data on other species of cetaceans and of other species of pinnipeds that have been reported in the Gulf of Guayqauil.

The total number of whale species (Cetacea) recorded by various researchers off the coast of Ecuador is 15, plus four species of pinnipeds (Palacios et al., 1997; Alava \& Carvajal, 2005; O’Hern et al., 2010; Félix et al., 2011). Among the cetaceans, four species of baleen whales and 11 species of dolphins and toothed whales were encountered in Ecuadorian waters; among the pinnipeds (carnivorous seals and sea lions), three species belong to the Otariidae (eared seals), and one, to the Phocidae (earless or true seals). The maximum number of marine mammals species was encountered off the coast of the province of Santa Elena, north of Guayaquil. The commonest species were Humpback Whale (Megaptera novaeangliae) (27.5\%), Shortbeaked Common Dolphin (Delphinus delphis) (12.3\%), Southern Sea Lion (Otaria flavescens) (12.3\%), Bottlenose Dolphin (Tursiops truncatus) $(10.14 \%)$, and Pan- 
tropical Spotted Dolphin (Stenella attenuata) (9.42\%). All the species, except bottle-nose dolphins, demonstrated seasonal variations in numbers, connected with the availability of food stock and/or reproductive cycle.

Other, less common cetacean species that have been reported for the Ecuador continental margin areas are: Sei Whale (Balaenoptera borealis), Bryde's Whale (Balaenoptera edeni), Striped Dolphin (Stenella coerulealba), Risso's Dolphin (Grampus griseus), Shortfinned Pilot Whale (Globicephala macrorhynchus), Sperm Whale (Physeter macrocephalus), Dwarf Sperm Whale (Kogia sima), Orca or Killer Whale (Orcinus orca), Pygmy Killer Whale (Feresa attenuate), and Cuvier's Beaked Whale (Ziphius cavirostris). Pinnipeds include Galapagos Fur Seal (Arctocephalus galapagoensis) and Galapagos Sea Lion (Zalophus wollebaeki) (Palacios et al., 1997). Southern Elephant Seals Mirounga leonina or M.angustirostris were encountered offshore in the Gulf of Guayaquil twice (in 1998 and 2002, Alava \& Carvajal, 2005), and the only encounter with a Blue Whale Balaenoptera musculus in the last 15 years in the Gulf of Guayaquil took place in 2007, 2 nautical miles $(\mathrm{nm})$ to the west of the Santa Elena Peninsula $\left(2^{\circ} 12^{\prime} 08^{\prime \prime} \mathrm{S}, 81^{\circ} 02^{\prime} 31^{\prime \prime} \mathrm{W}\right)$ (Félix et al., 2007).

As to the vicinity of the Santa Clara Island and the area of El Campo Amistad where we performed our observations, according to the published accounts, two species of cetaceans permanently reside here (Humpback Whale, Megaptera novaeangliae, and Bottlenose Dolphin, Tursiops truncatus), and one species of pinnipeds (Southern Sea Lion, Otaria flavescens) (Yturralde \& Suarez, 1998; Hurtado et al., 1998; Pinos et al., 2010). The biology of those species is sufficiently wellknown, so we shall consider each of them in more detail.

Annually, the southern population of Humpback Whales migrates to their breeding grounds in southeastern Pacifica, where they aggregate off the coasts of Ecuador, Columbia, and Panama (Dawbin, 1966; Scheidat et al., 2000; Félix \& Haase, 2001; O'Hern et al., 2010). Humpback Whales are encountered off the coast of Ecuador from May till November, but their numbers usually peak in July and August (Félix \& Haase, 2001, 2005). It is within those time limits when the whales are usually observed in the vicinity of the Santa Clara Island; the animals stay at 25 to $60 \mathrm{~m}$ depths (mean depth $45.7 \mathrm{~m}$; SD = 18.6) 20-30 km off shore (Yturralde \& Suárez, 1998). According to the latest population survey data obtained in 2010 in the vicinity of Salinas (Salinas, St. Elena Peninsula) and presented in the annual report to the Ministry of Environment of Ecuador, 839 Humpback Whales were recorded as present in this area (Alava et al., 2011).

Bottlenose dolphins, though, seem to be the only species of marine mammals permanently residing in the Gulf of Guayaquil. According to various estimates, the local population size amounts to approximately 2500 individuals. These animals fall into two ecological types: littoral (the Puna Island, the estuary of the Guayas River) and oceanic ones (Félix, 1994). Evidently, it is the latter type that is mainly encountered off the coast of the Santa Clara Wildlife Reserve and seaward. The size of migrating groups can vary from 50 to 160 and more animals (Stevenson, 1981).

Southern Sea Lions periodically migrate to the coast of Ecuador. This may be connected with temperature anomalies caused by the El Niño current. Small resident groups of males ( $\sim 10-30$ animals) were observed most commonly in two points: near Santa Clara Island and Punta Brava-Salinas. However, there were no hypotheses about the existence of permanent reproductive colonies there so far. All in all, at least 13 south sea lions locations (confirmed by visual observations, findings of skeletons or skulls) are known (Félix et al., 1994). All the above locations are evidently isolates; however, permanent or nearly permanent groups (at least 10 animals) reside in the Santa Clara national natural reserve in the Gulf of Guayaquil $\left(03^{\circ} 10^{\prime} \mathrm{S}\right.$, $80^{\circ} 27^{\prime} \mathrm{W}$ ); fishermen reported they saw young animals there in caves as well (Calle \& Suarez, 2003; B. Haase, pers. comm.). Another group of 12 Southern Sea Lions was encountered on Punta Brava, Salinas $\left(2^{\circ} 12^{\prime} \mathrm{S}\right.$, $81^{\circ} 00^{\prime} \mathrm{W}$ ) on the coast of Ecuador (Félix, 2002).

Thus, among the species under consideration only Bottlenose Dolphins and, possibly, Southern Sea Lions can be permanent residents of the Gulf of Guayaquil waters. The other species visit here on a seasonal basis or migrate through from time to time.

\section{Purposes and Tasks of Research}

Marine mammals were observed within the framework of seismic survey performed by the Russian OJSC "Sevmorgeo" in the vicinity of the Tumbes Bay, Gulf of Guayaquil off the south coast of Ecuador. The area under survey was situated completely off-shore. To the northeast, the area bordered the 4-mile buffer zone of the Santa Clara Island Wildlife Reserve (Fig. 1). The geographical coordinates of the nodal points are shown in the Table 1.

The size of the area under survey was $37 \mathrm{~km}^{2}$. The distance between the shore and the Tavr base vessel (BV) mooring was $29 \mathrm{~km}(16.6 \mathrm{~nm})$, that to the Puna Island, $33 \mathrm{~km}(18.3 \mathrm{~nm})$, to the Santa Clara island, 8.5 $\mathrm{km}(4.7 \mathrm{~nm})$. According to the charts of the Gulf of Guayaquil printed in 1990 by the Chief Directorate for Navigation \& Oceanography, depths within the borders of the area under survey varied from 37 to $58 \mathrm{~m}$.

The mission of the observer who worked on board the Tavr BV included:

Daytime detection of MMs on the way to the seismic survey performance area and during work on the seismic survey profiles;

The MM species identification and quantitative assessment;

Recording of the animals' behavior;

Photo and/or video recording of the research subjects.

The schedule of the Tavr BV during the summer survey period of the year 2013 is presented in Table 2 . 


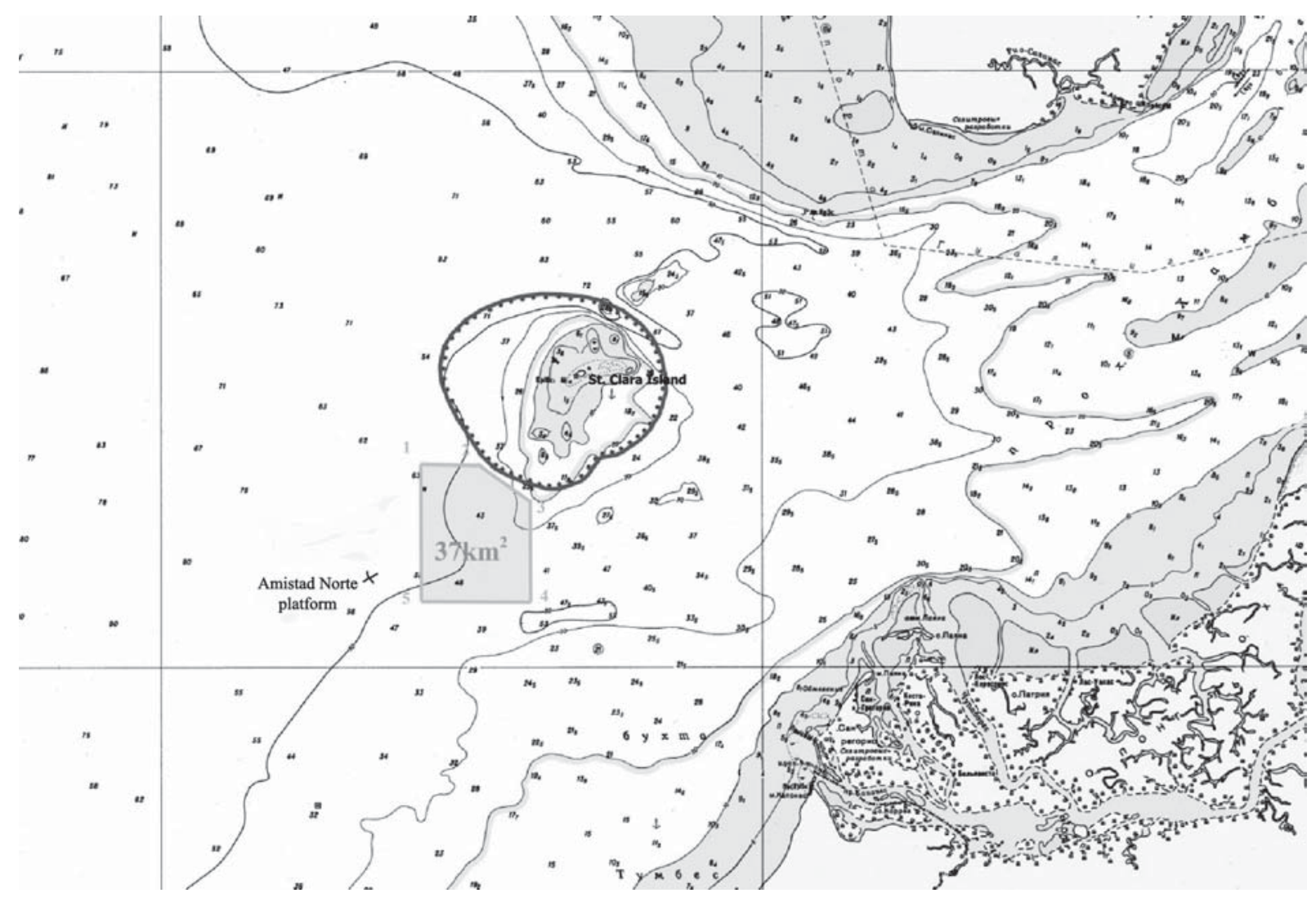

Fig. 1. Location of the area under survey. Grey rectangle: the survey area. Black border: the border of the Santa Clara Island wildlife Reserve buffer area.

Table 1. Geographical coordinates of the nodal points of the $37 \mathrm{~km}^{2}$ survey area.

\begin{tabular}{|l|c|c|}
\hline Point & Southern latitude & Western longitude \\
\hline 1 & 3,20314622 & 80,5026987 \\
\hline 2 & 3,20313057 & 80,4715575 \\
\hline 3 & 3,216327445 & 80,4503997 \\
\hline 4 & 3,263912584 & 80,4503740 \\
\hline 5 & 3,263939927 & 80,5026691 \\
\hline
\end{tabular}

Table 2. Tavr BV work schedule during the 2013 survey period.

\begin{tabular}{|l|l|c|}
\hline Vessel & Activity & Beginning and end \\
\hline \multirow{5}{*}{ Tavr } & $\begin{array}{l}\text { Moorage at the Bolivar port, coordinates: } \\
\text { S 03 } 26745 \text { W } 080^{\circ} 00514\end{array}$ & $25.03 .2013-16.05 .2013$ \\
\cline { 2 - 3 } & $\begin{array}{l}\text { Anchorage at the point with the following coordinates: } \\
\text { S 03 } 15.326 \text { W } 080^{\circ} 29.290\end{array}$ & $17.05 .2013-20.05 .2013$ \\
\cline { 2 - 3 } & Shifting to a new point & 20.05 .2013 \\
\cline { 2 - 3 } & $\begin{array}{l}\text { Anchorage at the point with the following coordinates: } \\
\text { S 03 } 13.479 \text { W } 080^{\circ} 29.172\end{array}$ & $20.05 .2013-02.06 .2013$ \\
\cline { 2 - 3 } & $\begin{array}{l}\text { Moorage at the Bolivar port, coordinates: } \\
\text { S } 03^{\circ} 16.0012 ; \text { W } 080^{\circ} 03.3117\end{array}$ & Since 02.06 .2013 \\
\hline
\end{tabular}


Table 3. Summary of observations performed in the course of marine mammals monitoring in the seismic survey area in May-June 2013.

\begin{tabular}{|l|c|}
\hline Parameter & Volume of Observations \\
\hline Total number of single observations performed & $147(100 \%)$ \\
\hline Total number of observation hours & 216 \\
\hline
\end{tabular}

Table 4. Meteorological observations performed in the seismic survey area and weather conditions in May-June 2013.

\begin{tabular}{|l|c|}
\hline Parameter & Volume of Observations \\
\hline Total number of continuous observation days & $3(17 \%)$ \\
\hline Number of days with precipitation in the form of rain & $11(65 \%)$ \\
\hline Number of days with fog (mist) & NW - WNW \\
\hline Predominant wind directions & $24-23-25$ \\
\hline Weekly variations of sea surface temperature $\left(\mathrm{C}^{\circ}\right)$ & 4 \\
\hline $\begin{array}{l}\text { Number of days when wind speed was less than } 0.5 \mathrm{~m} / \mathrm{s} \\
\text { (calm sea) }\end{array}$ & 6 \\
\hline Number of days when wind speed was more than $5 \mathrm{~m} / \mathrm{s}$ & 0 \\
\hline $\begin{array}{l}\text { Number of days when wind speed was more than } 10 \mathrm{~m} / \mathrm{s} \\
\text { (sea state grade exceeds 4) }\end{array}$ & \\
\hline
\end{tabular}

\section{Material and Methods}

The MM were detected visually with the help of Pentax 8-20X24 binoculars and a T-80A 30-60 X telescope. The detection data were recorded in a diary with the purpose of preserving the continuity of observations. Afterwards they were entered into a laptop computer; the actions were coordinated with the project contractors via vessel radio stations.

Observations were performed from the vessel radar platform or command bridge. Such a position ensured at least $270^{\circ}$ field of vision ahead of the ship; the Tavr BV wheelhouse height above sea surface was $12.8 \mathrm{~m}$. When marine mammals were detected, observers moved from the wheelhouse to the open deck areas that were most suitable for observations at that moment.

Observations were performed on a regular basis in daylight hours (from 5.30 a.m. till 07.00 p.m.), but when the seismic equipment was in operation, observations were performed continuously as much as visibility allowed. The BV location permitted one to track the animals location throughout the work area, to assess distance to them, and to calculate their motion direction and other aspects of their behavior (see Appendix).

The detection and recording of the marine mammals were performed by the biologist-observer and the crew members of the Tavr BV, as well as those of the work boats (WB). In addition, information about the MM presence or absence within the water area borders was received in the process of daily survey of seismic sensors that was performed on motor boats.

Regular log entries during watches were made every two hours. Whereupon the following data were recorded: the vessel location latitude and longitude, the vessel heading, state of the sea by the Beaufort scale, the observation period (daylight hours or hours of darkness), visibility, the shining of the sea surface and its location, the nature of the vessel activity.

When sea mammals were detected, an annotated entry was made to the observations log, and the following data were recorded: the coordinates of the point of encounter, the animal species, the number of animals, their behavior, the directions from which they appeared and where they are heading, the distance between them and the vessels. Primary identification of marine mammals was based on several generally accepted field guides (Jefferson et al., 1993; Merlen, 1995; Burdin et al., 2009).

Weather conditions were recorded at 6 hours intervals (4 times daily) by the thermometer/hygrometer, vessel instruments, and visually. The entries included data on cloud cover $(\%)$, temperature $\left({ }^{\circ} \mathrm{C}\right)$, humidity $(\%)$, wind speed $(\mathrm{m} / \mathrm{s})$ and direction, the presence and nature of precipitation, fog, etc.

The number of observations performed in the process of marine mammals monitoring are summarized in Table 3 .

In general, weather conditions during the survey work were favorable for observations and relatively stable. The day/night temperature difference did not exceed $14^{\circ} \mathrm{C}$; the maximum wind speed, as a rule, was 4-5 m/s. The predominant winds were NW-WNW; however, by the end of the observation period, the wind direction changed to $\mathrm{W}$ and even SW. According to the INOCAR data, the temperature of surface ocean waters varied within the limits of $2^{\circ} \mathrm{C}$ (www.inocar.mil.ec, 2014). The meteorological observations data are summarized in Table 4. 
Table 5. Number of encounters with marine mammals and the number of animals recorded in the survey work area from board the Tavr BV and the work boats (WB).

\begin{tabular}{|l|l|l|c|c|}
\hline $\begin{array}{l}\text { Item } \\
\text { No }\end{array}$ & Vessel & Marine Mammals Species & $\begin{array}{c}\text { Number of } \\
\text { Encounters }\end{array}$ & $\begin{array}{c}\text { Total Number } \\
\text { of Animals }\end{array}$ \\
\hline 1 & WB & unidentified toothed whales (dolphins)* & 1 & 12 \\
\hline 2 & Tavr & unidentified toothed whales (dolphins)* & 1 & 4 \\
\hline 3 & Tavr & Striped Dolphin, Stenella coeruleoalba & 1 & $\geq 30$ \\
\hline 4 & Tavr & Bottlenose Dolphin, Tursiops truncatus & 3 & $\geq 80$ \\
\hline 5 & WB & Humpback Whale, Megaptera novaeangliae* & 1 & 1 \\
\hline 6 & WB & Killer Whale, Orcinus orca & 3 & 9 \\
\hline 7 & Tavr & (Southern) Sea Lion, Otaria flavescens & 8 & 2 \\
\hline 8 & Tavr & Unidentified seal & 2 & 3 \\
\hline 9 & Tavr & Unidentified seal & 1 & 1 \\
\hline \multicolumn{2}{|l}{ TOTAL: } & $5(7)$ & 21 & $\geq 140$ \\
\hline
\end{tabular}

* animals detected by non-staff observers.

\section{Marine Mammal Recording Results}

More than $140 \mathrm{MMs}$ were sighted during the period of seismic survey. But it is virtually impossible to specify the precise number of individuals encountered when large shoals of dolphins were registered from the board of the Tavr BV and the work boats, during vessels shifting, and in the work area during the period of observations, namely from May 12 till June 2, 2013. There were 21 encounters with animals of five species (Tab. 5; Appendix).

In contrast, the number of marine mammals encounters by BV and work boats outside times or areas of seismic survey during the observations period was greater by an order of magnitude. Although no controlled exposure experiments were carried out, some groups of MMs apparently avoided the $37 \mathrm{~km}^{2}$ field area when active seismic survey was going on there.

As it can be seen from the analysis of obtained data, weather conditions did not impact the success of marine mammals recording in a substantial way. This can be explained by a stable weather, as well as absence of weather abnormalities: storm, thick fog, etc. Permanent ripples were not a major problem, but when wind grew stronger wavelets and "white caps" made the observer's tasks more complicated, especially at long distances. Obtained data series do not permit us to speak positively about the impact of the above factors on the completeness of records; however, we can assert that sea state increases from 0 to 1.5 did not seem to influence the number of MM encounters. No regularity had also been revealed between changes in the temperature regime of surface waters in this water area and the succeeding appearance of MM.

Here is a brief analysis of observation occasions in respect of each species of the MM.

Most observations were performed at a distance of 400-700 $\mathrm{m}$. Therefore, it was not always possible to identify the species of animals with certainty, especially for non-staff observers. However, in the majority of cases identification did not raise any doubts.

The behavior of the Bottlenose Dolphins (Tursiops truncatus Montagu, 1821), observed from board of Tavr BV and the escort vessels on May 22 and 31 was typical for this species. The animals formed compact groups numbering from 30 to 50 and followed the vessels at a distance from 600 to $700 \mathrm{~m}$ at an uniform speed without jumping above water. Uniform coloring and a characteristic shape of the dorsal fin permitted one to identify this cetacean species easily enough. It should be noted that both cases of Bottlenose Dolphins encounters in the area under survey coincided with the arrival of large shoals of schooling fishes.

Striped Dolphins (Stenella couruleoalba Meyen, 1833) were encountered only once, on May 19. There was a group of approximately 40 animals. Similar to Bottlenose Dolphins, they moved in a thick group at a rather high speed, about $300-400 \mathrm{~m}$ from the BV. Relatively small size, traces and their habit of jumping (sometimes they switch to «hydroplaning») permitted us to identify this species.

Unidentified dolphins. On May 12, a group of 12 dolphins was detected from a work boat during a test of sources. They moved parallel to the boat. Judging by their manner of moving and behavior, they were most probably Bottlenose dolphins. But a group of four animals encountered on the 20th of May cannot be identified on the basis of available information.

Other groups of large dolphins 3 or 5 animals strong were identified as Killer Whales (Orcinus orca Linnaeus, 1758). These groups were detected twice during the 19th of May. The animals moved in a line at a distance of 150-200 m from each other; they jumped highly from time to time. These orcas may have been in pursuit of a large shoal of school fish. Another encounter of a Killer Whale was recorded by A. Yakovlev on May 26. 
Judging by the description, it was a single juvenile animal.

Humpback Whale (Megaptera novaeangliae Borowski, 1781). A Humpback Whale was encountered within the survey work area only once by operator R. Douglas from a work vessel. The whale surfaced briefly and then submerged in a manner characteristic for this species. According to literature and reports of our Ecuadorian colleagues, Humpback Whales en mass occur in this water area at least 10-12 days later than the actual date of our work expiry.

Southern Sea Lion (Otaria flavescens Shaw, 1800). A single sea lion, and then a pair of them were encountered by the Tavr BV more than once. Judging by the constancy of their visits, the work area was within the borders of those animals' individual hunting area.

Unidentified seals: judging by the frequency of encounters, the was probably the same pair of $O$. flavescens, although the occurrence of Galapagos Sea Lion (Zalophus wollebaeki Sivertsen, 1953) is possible in this water area as well. On May 27, a playing/courtship behavior of the unidentified couple was recorded.

\section{Conclusions}

The general conclusions on the nature of distribution and the numbers of marine mammals in the surveyed area during the period of our observations are as follows:

The diversity of marine mammals species in the surveyed area matched expectations. It was limited to four species of cetaceans and one pinnipedian. Unidentified cetaceans and pinnipeds likely belong to one of the species mentioned above.

The density of the marine mammals population within the borders of the survey area was generally low (there were no mass aggregations). It is confined to the shallowest parts of the water area or the depth drop-off area in the northern part of the surveyed area. Their occurrence within the borders of the area under survey was temporary (possibly, except sea lions). Most probably it was connected with migrations of schooling fish shoals. Transitory penetration of cold surface water masses from the Peru coastline in the second ten-day period of May did not influence noticeably the temperature regime of the bay water, and no visible affect on the frequency of meetings between Bottlenose dolphins and sea lions was found. The latter species appeared relatively regularly during the entire observation period. Striped Dolphins, presumably associated with the open ocean, were also recorded in the bay before the mentioned changes.

The latter meeting is noteworthy for the Santa Clara Island water area. According to the literature, this species was previously reported near Salinas, St. Elena Peninsula, but as a whole, it is not typical of the Gulf of Guayaquil area (Van Waerebeek et al., 1998).

\section{Acknowledgments}

I extend my sincere gratitude to my fellow expedition members, the crews of the Tavr BV and the work boats for their help in our work, as well as the Petroamasones INC supervisors for discussions and the exclusive materials from the Santa Clara Wildlife Reserve Management Plan made available to us.

\section{References}

Alava J.J. \& Carvajal R. 2005. First records of elephant seals on the Guayaquil gulf, Ecuador: on the occurrence of either a Mirounga leonina or M. angustirostris // Latin American Journal of Aquatic Mammals (LAJAM). Vol.4. No.2. P.195-198.

Alava J.J., Barragán M.J. \& Denkinger J. 2011. Assessing the impact of bycatch on Ecuadorian humpback whale breeding stock: A review with management recommendations //http://dx.doi.org/10.1016/j.ocecoaman.2011. 11.003.

Burdin A.M., Filatova O.A. \& Hoyt E. 2009. [Marine Mammals of Russia]. Kirov: Volgo-Vyatskoye knizhnoe Izdatel'stvo. 210 p. [in Russian].

Calle M. \& Suarez H. 2003. Estado poblacional de las aves marinas residente del Refugio de Vida Silvestre-Isla Santa Clara para los meses de Diciembre 2002 y Julio 2003. Guayaquil, Ecuador: EDC, Ministerio del Ambiente. 17 p.

Dawbin W.H. 1966. The seasonal migratory cycle of humpback whales // Norris K.S. (ed.). Whales, Dolphins, and Porpoises. Berkeley and Los Angeles: University of California Press. P.145-170.

Félix F. 1994. Ecology of the coastal bottlenose dolphin Tursiops truncatus in the Gulf of Guayaquil, Ecuador // Investigations on Cetacea. Vol.25. P.235-256.

Félix F., Haase B., Samaniego J. \& Oechsle J. 1994. New evidence of the presence of the South American sea lion Otaria flavescens (Carnivora: Pinnipedia) in Ecuadorian waters // Estudios Oceanológicos. Vol.13. P.85-88.

Félix F. \& Haase B. 2001. The humpback whale off the coast of Ecuador, population parameters and behavior // Revista de Biologia Marina y Oceanografia. Vol.36. No.1. P.61-74.

Félix F. 2002. Una colonia de lobos marinos sudamericanos (Otaria flavescens) en Salinas, Ecuador // Acta Oceanografica del Pacifico. Vol.11. No.1. P.327-331.

Félix F. \& Haase B. 2005. Distribution of humpback whales along the coast of Ecuador and management implications // Journal of Cetacean Research and Management. Vol.7. No.1. P.21-31

Félix F., Botero N. \& Falconn J. 2007. Observation of a blue whale (Balaenoptera musculus) feeding in coastal waters of Ecuador // Latin American Journal of Aquatic Mammals (LAJAM). Vol.6. No.2. P.193-197.

Félix F., Jiménez P., Falconí J. \& Echeverry O. 2007. New records and first births of the Galapagos fur seal, Arctocephalus galapagoensis (Heller, 1904), from the mainland coast of Ecuador // Revista de Biología Marina y Oceanografía. Vol.42. No.1. P.77-82.

Félix F., Haase B., Denkinger J. \& Falconí J. 2011. Varamientos de mamíferos marinos registrados en la costa continental de Ecuador entre 1996 y 2009 // Acta Oceanográfica del Pacífico. Vol.16. No.1. P.61-73.

Gerrodette T. \& Palacios D.M. 1996. Estimates of cetacean abundance in EEZ waters of the eastern tropical Pacific. 
SWFSC Admin. Rept. LJ-96-10. 28 p. [in English and Spanish].

Hurtado M., Valle C., Yturralde G. \& H. Suárez. 1998. La Isla Santa Clara: Potencial nueva Área Marina y Costera Protegida en el Ecuador // Ponencia presentada en el Seminario Internacional sobre "El Estado del Ambiente Marino Costero en el Pácifico Sudeste". Guayaquil, 7 10 de Noviembre de 1998.

Jefferson T.A., Leatherwood S. \& Webber M.A. 1993. FAO Species Identification Guide. Marine Mammals of the World. Rome: FAO. 320 p.

Merlen G. 1997. A Field Guide to the Marine Mammals of the Galapagos: Cetacea, Pinnipedia. Puerto Ayora: Charles Darwin Foundation. 248 p.

O'Hern J.E., Mullin K.D., Biggs D.C. \& E. Pinto Uscocovich. 2010. Marine Mammal Habitat in Ecuador: Seasonal Abundance and Environmental Distribution. Southeast Fisheries Science Center National Marine Fisheries Service, Report. 5 p.

Palacios D.M., Félix F., Florez-Gonzalez L., Capella J.J., Chiluiza D. \& Haase B. 1997. Sightings of Galapagos sea lions (Zalophus californianus wollebaeki) on the coasts of Colombia and Ecuador // Mammalia. Vol.61. No.1. P.114-116.

Pinos O.Q., Sánchez E., Lasso S. \& Pozo M. 2009. Plan de Manejo del Refugio de Vida Silvestre Isla Santa Clara 2009-2019. Machala-Ecuador: Ministerio del Ambiente del Ecuador. 191 p.

Scheidat M., Castro C., Denkinger J., González J. \& Adelung D. 2000. A breeding area for humpback whales (Megaptera novaeangliae) off Ecuador // Journal of Cetacean Research and Management. Vol.2. No.3. P.165172.

Stevenson M.R. 1981. Variaciones estacionales en el Golfo de Guayaquil, un estuario tropical // Instituto Nacional de Pesca de Ecuador, Boletín Científico y Técnico. Vol.4. No.1. P.5-32.

Van Waerebeek K., Félix F., Haase B., Palacios D.M., MoraPinto D.-M. \&Munoz-Hincapie M. 1998. Inshore records of the striped dolphin, Stenella coeruleoalba, from the Pacific Coast of South America // Reports of the International Whaling Commission. No.48. P.525-532.

Yturralde G. \& Suárez H. 1998. Observaciones de especies indicadoras a bordo del barco de prospeccion sismica Western Inlet. Informe de viaje del Monitoreo Ambiental del Bloque 3 en el Golfo de Guayaquil // Hurtado M., Cavaria J., Suárez H. \& Yturralde G. (eds.). Monitoreo Ambiental del area marina del Bloque 3 el el Golfo de Gauyaquil durante la prospeccion sismica realizada en 1998. Informe final de cosultoria presentado a EDCEcuador Ltd. (unpublished report). 105 p.

Instituto Oceanográfico de la Armada INOCAR Producto: http://www.inocar.mil.ec/web/index.php/productos/temperatura-superficial-del-mar

\section{Appendix}

Table of observations: vessel locations, ambient conditions and encounters with animals in the process of marine mammal monitoring in the Gulf of Guayaquil on the Pacific Coast of Ecuador in May-June 2013.

Glare amount: NO — none; LI — slight; MO — moderate; SE — strong.

Glare position and the MM detection/motion direction by 12 hours clock face.

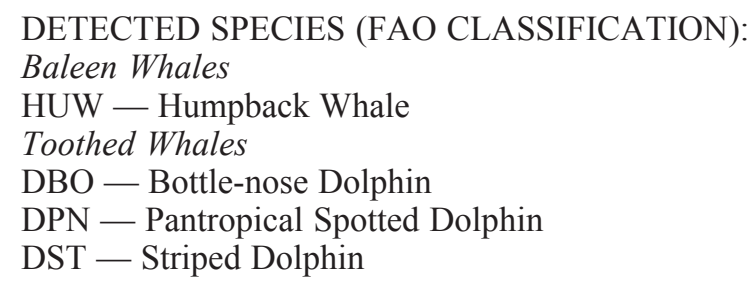

KIW - Orca; Killer Whale

UTW - Unidentified Tooth Whale

Eared seal

GSL - Galapagos Sea Lion

SSL - Southern Sea Lion

US - Unidentified seal

MOTION IN RELATION TO THE VESSEL:

$\mathrm{PE}$ - Perpendicularly

ST - Swim Toward

SA - Swim Away

FL - Flee

SP - Swim Parallel

MI - Mill
OBSERVED ACTIVITY TYPES:

SI - Sink

DI - Dive

LO - Look

SW - Swim

$\mathrm{BR}$ - Breach

$$
\begin{aligned}
& \text { FE - Feed } \\
& \text { BL - Blow } \\
& \text { PO - Porpoising } \\
& \text { CB - Courtship behavior } \\
& \text { PB - Play behavior }
\end{aligned}
$$

BEHAVIORAL REACTIONS INTENSITY: SE — Sedate; MO — Moderate; VI — Vigorous. 


\begin{tabular}{|c|c|c|c|c|c|c|c|c|c|c|c|c|c|c|c|c|c|c|c|}
\hline DISTANCE TO SHIP, MILES & $?$ & $\left|\begin{array}{l}0 \\
0 \\
0 \\
0\end{array}\right|$ & $\mid$ & $\stackrel{\Xi}{0}$ & $\mid$ & $\stackrel{t}{0}$ & $\begin{array}{l}0 \\
0\end{array}$ & $3:$ & $\begin{array}{lll}n & 0 \\
0 & 0 & \end{array}$ & $\stackrel{0}{\circ}: 0$ & $\stackrel{0}{0}$ & $\overrightarrow{0}$ & $\mid$ & $\overrightarrow{0}$ & $\ddot{o}$ & $\stackrel{m}{0}$ & $\begin{array}{l}\sim \\
0 \\
0\end{array}$ & & 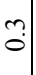 \\
\hline DIRECTION OF REVEALING & 으 & 으 & $m$ & 6 & $n$ & $\checkmark$ & $n$ & 6 & $\infty r$ & $r$ & 띠 & $r$ & $\infty$ & 0 & $\sim$ & $r$ & $n$ & in & $n$ \\
\hline DIRECTION TO & $\overline{0}$ & 6 & $=$ & $\simeq$ & $r$ & $\simeq$ & 의 & 1 & $\simeq 9$ & $\simeq$ n & 3 & -0 & $m$ & 으. & $=$ & 6 & $\nabla$ & $\approx$ & $\simeq$ \\
\hline DIRECTION FROM & 5 & $\simeq$ & $\nabla$ & 6 & $n$ & $\nabla$ & in & 1 & $\infty r$ & $r$ & 山 & 0.0 & $\infty$ & 0 & $\mathrm{~N}$ & $r$ & $\operatorname{nn}$ & 6 & 6 \\
\hline MOVEMENT PACE & 晃 & $\sqrt[n]{2}$ & 崩 & $\stackrel{0}{\Sigma}$ & 至 & 乩 & 뇡 & & $\stackrel{0}{\Sigma}$ & $\stackrel{0}{\Sigma} \mid \frac{0}{\Sigma}$ & $\sqrt[n]{n}$ & $\stackrel{0}{\Sigma}$ & 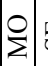 & $\stackrel{\sim}{\infty}$ & $\stackrel{0}{\Sigma}$ & 穼 & $\frac{0}{\Sigma}$ & & $\frac{0}{\Sigma}$ \\
\hline BEHAVIOUR & @ & 当 & 当 & 0 & 党 & $\stackrel{2}{\infty} \vec{I}$ & 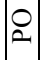 & & 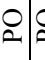 & ol & $\vec{\infty} \bar{\infty}$ & 尚 & 常 & 定 & 勇 & $\stackrel{m}{\infty}$ & $\vec{a}$ & $\mid$ & 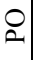 \\
\hline MOVEMENT MM I.R.T. VESSEL & थे & $\stackrel{\sim}{\infty}$ & 䎡 & $\ddot{\sim}$ & $\varangle$ & $\approx$ & 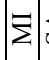 & 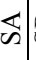 & ڤి & $\tilde{n} \mid \overleftrightarrow{\infty}$ & 芯 & $\ddot{\omega}$ & $\overleftrightarrow{\sim} \mid$ & 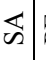 & 空死 & $\mathbb{n}$ & $\varangle$ & $\mid \begin{array}{r}\mid \\
\infty\end{array}$ & $\ddot{\sim}$ \\
\hline NUMBER OF INDIVIDUALS MM & $\cong$ & - & - & 우 & - & m & $n$ & $\nabla$ & 이 & 이- & - & -7. & - & - & -- & N & - & $\sim$ & in \\
\hline SPECIES & 3 & $\vec{\omega}$ & $\mid \begin{array}{l}\overrightarrow{\tilde{a}} \\
\tilde{\omega}\end{array}$ & $\vec{n}$ & $\overrightarrow{\widehat{a}}$ & 约 & 3 & 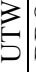 & 宓 & 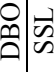 & $\sum^{3}$ & & $\hat{\tilde{n}}$ & $\tilde{D}$ & 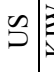 & $\mathscr{D}$ & & & $\begin{array}{l}0 \\
\hat{n} \\
\hat{\theta}\end{array}$ \\
\hline GLARE POSITION & 1 & $\infty$ & $m$ & 1 & $\nabla$ & $\sim$ & $\mathrm{N}$ & 1 . & $\simeq \approx$ & $\simeq 1$ & 1 & & $=$ & -1 & $\simeq$ & a & $\nabla$ & 1 & 1 \\
\hline GLARE AMOUNT & $\stackrel{\vartheta}{Z}$ & $\exists$ & 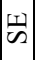 & 1 & 昰 & 贸 & 亚 & 1 & 뎅 & | & 1 & & w & $\Xi$ & $\sum_{\Sigma}^{0} 0$ & $\stackrel{0}{\Sigma}$ & 岀 & 1 & 1 \\
\hline LIGHT OR DARK & -1 & - & - & - & -1 & 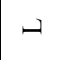 & - & $\stackrel{\Delta}{\hat{\theta}}$ & 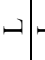 & - & $\stackrel{\vec{\Delta}}{\Delta}$ & $\stackrel{1}{\Delta}$ & - & נـ & ـــ & ــ & - & $\stackrel{2}{\epsilon}$ & ـ \\
\hline VISIBILITY, MILES & 6 & $\infty$ & $\infty$ & $r$ & $r$ & $\infty$ & $\infty$ & 8 & $6 \cdot 4$ & $n m$ & $\stackrel{\text { Iִ }}{\sim}$ & $\sim$ & 6 & - & $-y$ & $\infty$ & - & $\because$ & + \\
\hline SEA STATE, BEAUFORT SCALE & 0 & - & - & $\because$ & - & - & -1 & $?$ & -7 & -3 & $\ddot{0}$ & 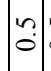 & $\because$ & $n$ & $\because$ & 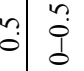 & & $\because$ & $?$ \\
\hline VESSEL HEADING & 3 & $\mid$ & $\mid$ & 它 & $\left|\begin{array}{l}u \\
z \\
z\end{array}\right|$ & 岁 & 光 & 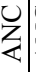 & $z_{1}$ & $3 \mid$ & ๙. & Z & 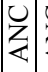 & 岁 & 安 & $\begin{array}{l}u \\
z\end{array}$ & 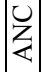 & & 岁 \\
\hline $\begin{array}{l}\text { LONGITUDE } \\
\text { HUNDRETH MINUTES }\end{array}$ & & ì & ৯ & ஓ & ৯ & $\stackrel{\text { ণ }}{ }$ & ঐ) & : & $\mathfrak{I}$ & 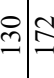 & $\dddot{f}$ & 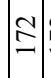 & $\mathbb{N}$ & $\stackrel{\mathbb{N}}{-}$ & $\stackrel{I}{I}$ & 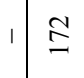 & I & $\frac{-1}{5}$ & I \\
\hline LONGITUDE MINUTES & 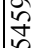 & సे & $\grave{\mathrm{N}}$ & Әे & ते & Әे & શิ & ते & సेळ & নે|নे & নे & શे & बे & ৯े & ते & নे & ลे & নิ & $\grave{\imath}$ \\
\hline LONGITUDE DEGREES & & $\infty$ & $\infty$ & $\infty$ & $\triangleright$ & $\triangleright$ & $\triangleright$ & 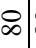 & $\triangleright ১$ & $\triangleright \otimes$ & $\infty$ & $\triangleright$ & $\triangleright$ & $\triangleright$ & $\triangleright$ & $\infty$ & $\infty$ & $\infty$ & $\infty$ \\
\hline LATITUDE HUNDRETH MINUTES & & $\left|\begin{array}{l}0 \\
\text { ñ } \\
\text { n. }\end{array}\right|$ & 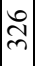 & $\begin{array}{l}\stackrel{0}{2} \\
\sim \\
\sim\end{array}$ & $\begin{array}{l}0 \\
\text { ñ }\end{array}$ & 光 & $\begin{array}{l}0 \\
\text { } \\
m\end{array}$ & है & $\stackrel{\vartheta}{\vec{\gamma}}$ & 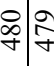 & 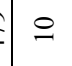 & $\frac{a}{\gamma}$ & $\underset{\gamma}{\partial}$ & $\stackrel{\vartheta}{\vec{\gamma}}$ & જे & $\stackrel{\curvearrowright}{\frac{\gamma}{f}}$ & शे & 字 & $\frac{\vartheta}{\gamma}$ \\
\hline LATITUDE MINUTES & वे & $\because$ & $\because$ & $\because$ & $\because$ & $\because$ & $\approx$ & 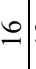 & $m=$ & $\approx=$ & $\stackrel{0}{-}$ & $=$ & $\because$ & 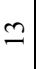 & $\underline{n}$ & $\underline{m}$ & $\approx$ & $\approx$ & 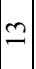 \\
\hline LATITUDE DEGREES & & $\tilde{8}$ & $\tilde{\delta}$ & m & $\tilde{\theta}$ & o & 2 & 8 & ชิ & $\tilde{8}$ & o & 8 & $\tilde{\sigma}$ & \% & \% & 8 & $\tilde{\theta}$ & $\approx$ & ชิ \\
\hline TIME, MINUTE & i & $\hat{\imath}$ & $\infty$ & $\approx$ & m & q & ิ) & fo & T & $ঃ \bar{ন}$ & ిల & 0 & $\delta$ & $\mathscr{F}$ & in & $\tilde{\delta}$ & if & & in \\
\hline TIME, HOUR & $\because$ & $\because$ & 으 & \& & $\infty$ & $\simeq$ & $=$ & 8 & $\Rightarrow=$ & \pm & $\stackrel{\infty}{\sim}$ & 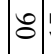 & $=$ & $\simeq$ & $\because=$ & $=$ & 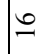 & $\infty$ & 8 \\
\hline DATA & 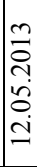 & 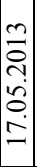 & 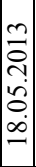 & $\begin{array}{l}m \\
\tilde{D} \\
\tilde{n} \\
0 \\
0 \\
2\end{array}$ & 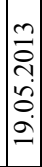 & 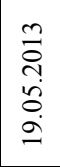 & $\begin{array}{l}m \\
2 \\
0 \\
\vdots \\
0 \\
2 \\
-\end{array}$ & 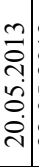 & 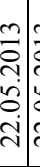 & 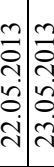 & 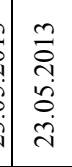 & 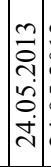 & 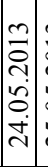 & 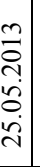 & 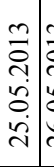 & 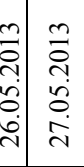 & 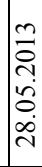 & 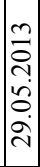 & 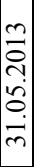 \\
\hline
\end{tabular}

